\title{
Active teaching model to promote critical thinking
}

\author{
Modelo de ensino ativo para o desenvolvimento do pensamento crítico \\ Modelo de enseñanza activo en el desarrollo del pensamiento crítico
}

\section{Fábio da Costa Carbogim' \\ ORCID: 0000-0003-2065-5998}

Larissa Bertacchini de Oliveira"

ORCID: 0000-0001-9509-4422

Melina Mafra Toledo"'I

ORCID: 0000-0002-2727-2933

Flávia Batista Barbosa de Sá Diaz ${ }^{1 V}$ ORCID: 0000-0003-2360-3026

Greicy Kelly Gouveia Dias Bittencourt ${ }^{v}$ ORCID: 0000-0001-5287-8171

Vilanice Alves de Araújo Püschel" ORCID: 0000-0001-6375-3876

Universidade Federal de Juiz de Fora. Juiz de Fora, Minas Gerais, Brazil. "Universidade de São Paulo, Escola de enfermagem. São Paulo, São Paulo, Brazil.

"' Escola Superior de Ciências da Saúde. Brasília, Distrito Federal, Brazil.

" Universidade Federal de Viçosa. Viçosa, Minas Gerais, Brazil. $\checkmark$ Universidade Federal da Paraíba. João Pessoa, Paraíba, Brazil.

How to cite this article: Carbogim FC, Oliveira LB, Toledo MM, Diaz FBBS, Bittencourt GKGD, Püschel VAA. Active teaching model to promote critical thinking. Rev Bras Enferm [Internet]. 2019;72(1):293-8. DOI: http://dx.doi.org/10.1590/0034-7167-2018-0002

Corresponding Author: Fábio da Costa Carbogim E-mail: fabiocarbogim@gmail.com

Submission: 05-10-2017

Approved: 07-29-2018

\section{ABSTRACT}

Objective: To present the experience of elaboration and implementation of the Active Teaching Model to Promote Critical Thinking (MEAPC), associated to ProblemBased Learning ( $P B L)$, for undergraduate students in Nursing. Method: Case report on the experience of the educational intervention (MEAPC + PBL) with undergraduate students in Nursing, in a 20-hour course on Basic Life Support (BLS). The MEAPC was validated by judges to guide the analysis of clinical cases. Critical Thinking (CT) skills were assessed using the California Critical Thinking Skills Test. Result: The educational intervention took place in two phases: elaboration and implementation, allowing not only the production of knowledge about BLS, but also the development of CT and exchange of experiences for teaching-learning. Conclusion: The association of the MEAPC to the PBL in the course of BLS organized the learning, gave opportunity to acquire knowledge and to stimulate the skills of the CT.

Descriptors: Nursing; Education, Nursing; Problem-Based Learning; Thinking; Education, Higher.

\section{RESUMO}

Objetivo: Apresentar a experiência de elaboração e implementação do Modelo de Ensino Ativo para o Desenvolvimento do Pensamento Crítico (MEAPC), associado ao Problem-Based Learning (PBL), para estudantes de graduação em Enfermagem. Método: Relato de experiência da intervenção educativa (MEAPC + PBL) com estudantes de graduação em Enfermagem, em um curso de 20 horas sobre Suporte Básico de Vida (SBV). O MEAPC foi validado por juízes com objetivo de nortear a análise de casos clínicos. As habilidades de Pensamento Crítico (PC) foram avaliadas pelo instrumento California Critical Thinking Skills Test. Resultado: A intervenção educativa ocorreu em duas fases: elaboração e implementação, permitindo não apenas a produção de conhecimento sobre SBV, mas também o desenvolvimento do PC e troca de experiências para o ensino-aprendizado. Conclusão: A associação do MEAPC ao PBL em curso de SBV organizou o aprendizado, oportunizou aquisição de conhecimentos e o estímulo às habilidades do PC.

Descritores: Enfermagem; Educação em Enfermagem; Aprendizagem Baseada em Problemas; Pensamento; Ensino Superior.

\section{RESUMEN}

Objetivo: Presentar la experiencia de elaboración e implementación del Modelo de Enseñanza Activo para el Desarrollo del Pensamiento Crítico (MEAPC) asociado al Problem-based Learning (PBL) a estudiantes de grado en Enfermería. Método: Reporte de experiencia en la intervención educativa (MEAPC + PBL) con estudiantes de grado en Enfermería, de una materia de 20 horas sobre Soporte Básico de Vida (SBV). El MEAPC fue validado por jueces con el objetivo de orientar el análisis de casos clínicos. Las habilidades de Pensamiento Crítico (PC) fueron evaluadas por el instrumento California Critical Thinking Skills Test. Resultado: La intervención educativa ocurrió en dos fases: la elaboración y la implementación, y permitió no sólo la producción de conocimiento sobre SBV, sino también el desarrollo del PC y el intercambio de experiencias para la enseñanza-aprendizaje. Conclusión: La asociación del MEAPC al PBL en la materia de SBV organizó el aprendizaje, posibilitó la adquisición de conocimientos y el estímulo a las habilidades del PC.

Descriptores: Enfermería; Educación en Enfermería; Aprendizaje Basado en Problemas; Pensamiento; Educación Superior. 


\section{INTRODUCTION}

In the midst of global transience, critical thinking (CP) has been pointed as a directive tool to the diligent analysis of the issues and changes that influence daily life ${ }^{(1-2)}$. It is a skill that involves intellectual criteria of reflection and action, having a preponderant role in political, economic, social, family, professional and educational decisions, implying also in the construction of a just and democratic society ${ }^{(1)}$.

In this way, CT is a concept that reflects intellectual actions alluding to an organized, active and intentional effort to understand a situation or problem, including the careful evaluation of one's own thinking and of others ${ }^{(1-2)}$.

In nursing, it has been defined as the ability to use in professional actions the highest cognitive abilities, such as to analyze, to question, to evaluate, to conceptualize, comprehending individual and collective health problems in a more precise, logical and appropriate way. These skills directly implicate the achievement of adequate outcomes through effective clinical judgment and clinical decision-making (1).

In Nursing undergraduate courses, training professionals with critical thinking ability has become an essential guideline in the discussions promoted by educational institutions such as the Brazilian Nursing Association (ABEn) and the Ibero-American Network of Research in Nursing Education (RIIEE) (1). In this sense, it is expected that nursing graduates, in addition to the general and specific skills and abilities of the profession, will be able to evaluate and generate information, make decisions and solve problems through CT.

Studies ${ }^{(2-4)}$ point out that the use of learning methodologies that generate possibilities for student-teacher and student-student active and problematizing interaction has positive results in the acquisition of cognitive and metacognitive psychosocial skills such as $\mathrm{CT}^{(2-4)}$.

\section{OBJECTIVE}

To present the experience of elaborating and implementing the Active Teaching Model to Promote Critical Thinking (MEAPC), associated with Problem-Based Learning (PBL), as an educational intervention, in a Basic Life Support (BLS) course for graduation students in nursing.

\section{CASE REPORT}

\section{Preparation of Active Teaching Model to Promote Critical Thinking}

The authors understand by educational intervention a set of pedagogical activities, with specific methods, phases and rules aimed at the attainment of desirable skills and attitudes, through mobilizing and evaluating actions of knowledge.

Students, when participating in activities whose goal is the development of the CT at the end of the course, should be able to understand the logical principles of thinking and of metacognition (thinking about thinking), knowing how to solve problems, knowing how to seek and use knowledge, as well as how to evaluate the quality of the evidence found ${ }^{(4)}$. Thus, the facilitator/teacher should use methodological teaching strategies that allow students to participate actively in the teaching-learning process in a self-reflexive way, and to enable them to apply the knowledge acquired in practice.

Considering the need to carry out an educational intervention to stimulate and evaluate the CT in an BLS course ${ }^{(5)}$, we searched in the literature methodological teaching strategies promising in the development of CT. Thus, three systematic reviews were identified, which demonstrated the effectiveness of the $\operatorname{PBL}(2,6-7)$ in the development of the $\mathrm{CT}$ of nursing undergraduate students.

However, although PBL has demonstrated a relationship with $\mathrm{CT}$, we observed in the literature evaluated the need for a model that directly stimulated CT skills.

In this way, the MEAPC was created whose pedagogical structuring was based on the Activity Theory ${ }^{(8)}$, that is, it attributes the development of mental functions superior to the human and collective need, to appropriate the historically and culturally elaborated productions. It is in the relation with the social environment that the process of appropriation of knowledge will occur, provoked by the exchanges between the intra- and extra-psychic domain $s^{(8-10)}$. In this perspective, shaped into the teaching field through the organizing instrument called Activity Oriented Teaching (AOT) ${ }^{(9)}$ - which conceives the process of appropriation of knowledge in a dialectical movement of analysis and synthesis, going from the general to the particular and from the abstract to the concrete the AOT directs the process of building knowledge to the object of learning through the organization of teaching activities. Therefore, intellectual appropriation will occur through collective activity oriented to: share perceptions and meanings; inquire; establish consensus and produce actions focused on goals ${ }^{(8-9)}$.

Therefore, based on the Activity Theory ${ }^{(8)}$, AOT seeks to transform pedagogical objectives into teaching-learning outcomes through the actions of those involved, so there is a need to establish guiding elements, which are: subjects, content, conditions, objectives, operations and reasons ${ }^{(9)}$.

Figure 1 shows each of these guiding elements according to the activities developed in the course. It should be noted that the AOT permeated the entire BLS course, and the MEAPC was applied only on the second day.

It should be clarified that the AOT is an innovative pedagogical proposal in nursing education, however, for about two decades, it has been implemented in the fields of basic sciences and pedagogy ${ }^{(9)}$.

Based on the Activity Theory(8-9), students were stimulated to mental operations through the MEAPC associated to the PBL, creating new concepts and signs that, throughout the tasks, were clarified to arrive at problem solutions. Thus, the MEAPC is a tool that guides the development of CT and is based on both the AOT and the skills defined in the report produced by a consensus of experts for the promotion of CT, called The Delphi Report ${ }^{(11)}$. This report is used worldwide and it is the conceptual basis for several studies and tests/scales that evaluate CT. It is organized into four sections that address the concept of CT and ideal critical thinker, as well as $\mathrm{CT}$ skills and dispositions.

The MEAPC has six subdivisions (Chart 1), corresponding to the number of CT skills, which are: interpretation, analysis, evaluation, inference, explanation and self-regulation ${ }^{(11)}$. For each skill there is a description and specific guiding questions, which are generic 
regarding the skill to be taught, and they can be adapted to other problem situations or clinical cases. It aims to support a study that evaluates the development of CT through questions that organize the thinking for critical analysis. Thus, the questions are put as directives tools in the teaching activity to mobilize and to stimulate the students to analyze and critically inquire into a clinical case.

In this way, the structure of the instructional model proposed here intends to mobilize higher mental processes, fundamental to the development of CT. Instead of purely selfexplanatory and expository, it stimulates the active and problematizing interaction of students and facilitators/tutors.

Before the educational intervention, the guiding questions of the MEAPC, as well as its application proposal, were validated by judges. The selection was based on the following criteria: research professors in the field of Nursing who had at least three publications (books, articles, dissertation or thesis) in the last five years on CT, Brazilian or foreigners with a command of the Portuguese language. To identify these authors, a search was made for publications in Google Scholar with the descriptors: education in nursing and critical thinking (in Portuguese, Spanish and English). According to the frequency of publications, five national and three international experts (United States, Mexico and Spain) were selected. A message was sent by e-mail to the specialists inviting them to participate as labor judges, evaluating the pertinence, clarity and accuracy of the MEAPC, with a deadline of two months for analysis and response.

Four national and one international experts (Mexico) responded to the first e-mail, showing interest in participating. One month after the first e-mail, a new message was sent reminiscent of the deadline and again inviting those who did not respond to the first invitation. At the end of the two months, the deadline was extended for another month. Of the eight initially selected, only four experts responded, but only three returned to the evaluation, two of which were national and one international (Mexico). As there was no further possibility of postponing the intervention, the changes were made according to the weights of these three participants. After the modifications, the work was sent back to the three judges who validated the application.
Chart 1 - Active Teaching Model to Promote Critical Thinking, Viçosa, Minas Gerais, Brazil, 2015

\begin{tabular}{|l|l|}
\hline Skill 1 - Interpretation \\
\hline $\begin{array}{l}\text { Ability to understand and express sense or meaning to situations or } \\
\text { experiences. }\end{array}$ \\
\hline $\begin{array}{l}\text { Guiding } \\
\text { questions }\end{array}$ & $\begin{array}{l}\text { How do I interpret this situation? What knowledge do I need } \\
\text { to understand this situation? Have I experienced this before? }\end{array}$ \\
\hline Skill 2 - Analysis \\
\hline $\begin{array}{l}\text { Ability to identify logical and true conclusions about situations or } \\
\text { experiences }\end{array}$ \\
\hline $\begin{array}{l}\text { Guiding } \\
\text { questions }\end{array}$ & $\begin{array}{l}\text { What information is relevant for me to understand this } \\
\text { situation separately? Is there logic/meaning in actions? What } \\
\text { are myints of view on these actions? }\end{array}$ \\
\hline Skill 3 - Evaluation \\
\hline $\begin{array}{l}\text { Ability to examine the credibility of what is presented about situations or } \\
\text { experiences }\end{array}$ \\
\hline $\begin{array}{l}\text { Guiding } \\
\text { questions }\end{array}$ & $\begin{array}{l}\text { What information can be grouped to identify a problem? Did } \\
\text { the actions lead to adequate results? Are there strengths and } \\
\text { weaknesses in those actions? }\end{array}$ \\
\hline
\end{tabular}

To be continued 
Chart 1 (concluded)

Skill 4 - Inference

Ability to identify and draw rational conclusions out based on situations or experiences.

Guiding What are the problems identified and which are the priorities questions that require interventions? To what conclusions could I arrive regarding those problems? What other alternative actions can solve this problem?

Skill 5 - Explanation

Ability to express the results of a reasoning about situations or experiences; justify it based on evidence.

Guiding $\quad$ Based on identified problems, how should actions be questions planned? In this situation, how would you act? Do those actions find support in scientific evidence?

Skill 6 - Self-regulation

Ability to be self-conscious in situations or experiences; monitoring their own cognitive activities, the elements used in these activities, as well as the results extracted.

\begin{tabular}{l|l} 
Guiding & Doljudge the actions taken in this case impartially or
\end{tabular}

questions influenced by some prejudice? How do l evaluate the results? How do I rate myself in this activity?

Source: Adapted from Facione(11).

After validation, and one month before the first-aid course, training of tutors (facilitators) was carried out, which aided in the teaching process. The tutors were two professors of the Undergraduate Nursing course of the Federal University of Viçosa and two nurses. The preparation and validation of the MEAPC occurred between January and October 2015, and the intervention in November 2015.

\section{Implementation of the Active Teaching Model to Promote Critical Thinking}

The MEAPC was implemented in association with the PBL in a BLS course ${ }^{(5)}$ of 20 hours, electively offered to 52 undergraduate students of the Nursing Undergraduate Course of the Federal University of Viçosa, Minas Gerais. The students were enrolled between the first and seventh period of the course, excluding those who were removed for health reasons or who were between the eighth and the tenth period of the course. The purpose of this course was to provide students with basic technical-scientific knowledge about BLS and, concurrently, to stimulate the development of CT skills. For this, the activities were developed in three meetings, organized in order to mobilize knowledge through interaction, exchange of experiences and stimulation to CT.

The original study design of this report was approved by the Ethics and Research Committee of the Federal University of Viçosa.

The course was divided in three moments. On the first day, the contents that would be approached in the three days of the course were presented to the students using PowerPoint slides. This initial moment was also used to explain and clarify doubts about the PBL, its phases and objectives, as well as its association with MEAPC.

Then, specific tests were applied that evaluated CT skills through the California Critical Thinking Skills Test (CCTST), which is also based on the consensus established in the Delphi Report ${ }^{(11)}$ and is currently marketed by Insight Assessmet, located in California, United States of America. The test was validated in Portuguese by the company and it is divided into scales representing the skills of critical thinking: analysis, evaluation, inference, deduction, induction and general reasoning skills. These scales, consisting of approximately four or five questions each, make up the test that has 34 questions in total. After the test and a short interval break, a test was applied to assess the students' prior knowledge, elaborated by the authors, with 15 questions about BLS.

Before entering the contents of the second day, the students were divided into small work subgroups, with a maximum of ten components, under the guidance of a tutor. Following the logic of the PBL, a secretary and a coordinator were elected by the subgroup. The first one was responsible for the organization and notes of the group's surveys; the second was responsible for keeping the group focused, avoiding dispersal.

The second day corresponded to the intervention phase itself, in which the MEAPC associated to the PBL was used to stimulate CT skills. It should be noted that the MEAPC was inserted in the second stage of the PBL, because it is considered the most appropriate for the beginning of the organization and stimulus of the thought. This phase aimed to lead the student to think critically about a problem situation, to review and learn new concepts in the light of a creative, interactive and mediated process by the active action of the teacher. In this sense, mental operations rely on signs or instruments at the psychological level, which have the function of mediating the external and internal worlds, guiding them towards problem solving ${ }^{(8-10)}$.

After careful reading of the case and application of the MEAPC, the secretary should list, with the group's help, what it would take to deepen the understanding of the case. For each learning need a learning objective should be established followed by a plan of action to achieve it. With the objectives and action plan in mind, the students were asked to disperse and, in a group, to seek answers based on available evidence in the literature. For this, books, articles and two computer labs with 20 computers each for Internet consultation were made available.

This first moment of the PBL until dispersion occurred in the morning, with the afternoon reserved for the presentation of the results to the larger group. Each subgroup presented what they learned, in addition to reassessing the problem in the light of new knowledge by sharing and discussing information. Two groups, in addition to the theoretical content discussed, organized theoretical-practical activities with manikins under tutoring.

Based on this experience, the $\mathrm{AOT}^{(8)}$ made possible the organization of teaching that became an instrument of mediation of scientific knowledge in that it directed and defined the roles during the course. In addition, it is well known that teaching and learning pedagogical planning affect the cognition of active subjects by directing them to an interactive, critical and creative process of transforming reality ${ }^{(8)}$.

Far from being just an exposition of teaching knowledge, the instructional model (MEAPC + PBL) brought together materiality to the intervention, while problematizing possible situations in everyday life. On the one hand, the teacher oriented the construction of the solution of triggering teaching situations (situation-problem, signaling of unknown terms, study needs and group action plan to seek knowledge). On the other, students, after receiving the guidelines and having a plan of action, appropriated the content 
through materials indicated by the teacher, teacher orientation and exchange of experience among colleagues.

The third day of the course corresponded to the post-intervention evaluation, when the CCTST and the same 15 objective questions about BLS were applied again.

From the perception of the tutors, students' reports and comparison of the tests, before and after the intervention, it is noticed that there was development of CT skills and joint elaboration of new knowledge, not limited to the assimilation of BLS content. The students' initial insecurities were gradually replaced by confidence, mastery of activities, and satisfaction.

Regarding the test result, comparing the mean scores before and after the intervention, there was an improvement in CT skills, especially for analysis, which presented a statistically significant difference when compared to the pre-test. However, it should be noted that, in the pre-test, students already presented scores that reflected a consistent basis in all CT skills assessed by the scale.

Thus, this information corroborates with the principle that it is in the relation with the other that the possibilities of knowledge appropriation arise through the stimulus to the Zone of Proximal Development (ZPD) ${ }^{(10)}$. Otherwise, this is about bridging the gap between the actual level of development - that is, the current level of knowledge - and the level of potential development, another level at which one acquires problem-solving ability with the help of someone more experienced to, then, resolve it independently ${ }^{(10)}$.

And it is in this process that the encouragement to CT acts as regulator of the intellectual standards, impelling human potentiality. This implies the improvement of the reasoning skills, the search for new knowledge and ways of judging, making nurses able to prognosticate, diagnose and validate findings and then solve problems of practice, whether clinical, professional or social ${ }^{(12)}$.

\section{Study limitations}

It is highlighted as a limitation the non-accomplishment of a follow-up post-test to evaluate the permanence of CT skills. In addition, the intervention proposal in a single group of students, without control group for comparison, limits the evaluation of the intervention model effect.

\section{Contributions to the field of Nursing}

This case report may contribute to the nursing teaching practice, considering the methodological proposal of the MEAPC to be feasible, applicable to the improvement and stimulation of the CT. It is considered that the MEAPC associated to the PBL, as an instructional model of teaching, can be reproduced in the nursing undergraduate contexts, either in the BLS learning or another topic. In addition, it is believed that the proposal could collaborate for future interventions and research that evaluate CT development, serving as basis for the elaboration and implementation of teaching strategies that aim to stimulate CT skills.

\section{FINAL CONSIDERATIONS}

The experience of developing and implementing the educational intervention made it possible to realize the viability of an instructional model for nursing education, focusing on the stimulation of critical thinking skills, such as analysis, interpretation, evaluation, inference, explanation and self-regulation. In this way, the MEAPC + PBL enabled the improvement of skills and progress in the knowledge of Basic Life Support.

Regarding the results of the tests, for BLS, there was a significant improvement in the results, with statistical significance of the post-test and, for the critical thinking skills test, there was progress in the scores, with statistical significance for analysis ability.

In the field of nursing education, the model has shown to be a promising technology, aiming at stimulating critical thinking skills, essential for clinical reasoning and for improving of BLS knowledge. However, studies are recommended that replicate the pedagogical proposal of the MEAPC that has a control group and that performs follow-up post-test.

\section{REFERENCES}

1. Carbogim FC, Oliveira LB, Puschel VAA. Critical thinking: concept analysis from the perspective of Rodger's evolutionary method of concept analysis. Rev Lat Am Enfermagem [Internet]. 2016 [cited 2016 Oct 19];24:e2785. Available from: http://www.scielo.br/pdf/rlae/v24/ pt_01041169-rlae-24-02785.pdf

2. Oliveira LB, Diaz LJR, Carbogim FC, Rodrigues ARB, Puschel VAA. Effectiveness of teaching strategies on the development of critical thinking in undergraduate nursing students: a meta-analysis. Rev Esc Enferm USP [Internet]. 2016 [cited 2017 Dec 28];50(2):355-64. Available from: http://dx.doi.org/10.1590/S0080-623420160000200023

3. Carvalho DPSRP, Azevedo IC, Cruz GKP, Mafra GAC, Rego ALC, Vitor AF, et al. Strategies used for the promotion of critical thinking in nursing undergraduate education: a systematic review. Nurse Educ Today [Internet]. 2017 [cited 2017 Dec 24];57:103-7. doi: 10.1016/j. nedt.2017.07.010

4. Huang GC, Newman LR, Schwartzstein RM. Critical thinking in health professions education: summary and consensus statements of the Millennium Conference 2011. Teach Learn Med. 2014;26(1):95-102. doi: 10.1080/10401334.2013.857335

5. American Heart Association. Destaques da American Heart Association 2015: atualização das diretrizes de RCP e ACE [Internet]. Dallas: AHA; 2015 [cited 2017 Dec 21]. Available from: https://eccguidelines.heart.org/wp-content/uploads/2015/10/2015-AHA-Guidelines-HighlightsPortuguese.pdf

6. Kong LN, Qin B, Zhou YQ, Mou SY, Gao HM. The effectiveness of problem-based learning on development of nursing students' critical thinking: a systematic review and meta-analysis. Int J Nurs Stud. 2014;51(3):458-69. 
7. Yuan H, Willians BA, Fan L. A systematic review of selected evidence on developing nursing students critical thinking through problembased learning. Nurse Educ Today. 2008;28(6):657-63.

8. Leontyev AN. Actividad, consciência e personalidad. Buenos Aires: Ciências del Hombre; 1978. 307 p.

9. Moura MO, organizador. A atividade pedagógica na teoria Histórico-Cultural. Brasília: Liber Livro; 2010. 208 p.

10. Vygotsky LS. A construção do pensamento e da linguagem. São Paulo: Martins Fontes; 2010. 212 p.

11. Facione PA. Critical thinking: a statement of expert consensus for purposes of educational assessment and instruction - executive summary "The Delphi Report". Am Philosop Assoc. 1990;(650): 697-721.

12. Carvalho EC, Oliveira-Kumakura ARS, Morais SCRV. Raciocínio clínico em enfermagem: estratégias de ensino e instrumentos de avaliação. Rev Bras Enferm [Internet]. 2017 [cited 2018 Jan 6];70(3):662-668. Available from: http://www.scielo.br/scielo.php?script=sci_ arttext\&pid=S0034-71672017000300662\&lng=pt. http://dx.doi.org/10.1590/0034-7167-2016-0509 